\title{
DEVELOPMENT OF A DIPLOID CELL LINE FROM FETAL RHESUS MONKEY LUNG FOR VIRUS VACCINE PRODUCTION*
}

\author{
ROSLYN E. WALLACE AND PAUL J. VASINGTON \\ Lederle Laboratories Division, American Cyanamid Company, Pearl River, New York 10965
}

JOHN C. PETRICCIANI, HOPE E. HOPPS, AND DOUGLAS E. LORENZ

Bureau of Biologics, Food and Drug Administration, Rockville, Maryland 20852

ZDENEK KADANKA

University of Toronto, Connaught Medical Research Laboratories, Willowdale, Ontario, Canada

\begin{abstract}
Summary
The primary goal of this study was to develop and characterize diploid cell lines from fetal tissues of subhuman primates for use in virus vaccine production. Cell lines have been established from fetal tissues of rhesus and African green monkeys, and these have been characterized according to the general criteria recommended by the International Cell Committee for Microbiological Standardization. Of these cell lines, DBS-FRhL-2, developed from lung tissue of a rhesus monkey fetus, has been found to meet the requirements of populations proposed as substrates for virus vaccines.

Characterization studies show that DBS-FRhL-2 cells have a finite life of more than 50 population doublings in vitro and maintain the diploid karyotype through an active growth phase. The cells are nontumorigenic, and tests have not revealed the presence of adventitious agents. They are susceptible to a number of human viruses and can be preserved by freezing without change in virus susceptibility, cytogenetic, or growth characteristics. These results indicate the need for further evaluation of this rhesus monkey diploid cell line for acceptability as an alternate substrate in the manufacture of human virus vaccines.
\end{abstract}

Hayflick and Moorhead (1) have shown that human diploid cells (HDC) of fetal origin can be serially cultured through a limited number of passages, producing a theoretical limit of $10^{22}$ cells for each cell line ${ }^{1}$ capable of 50 population doublings. When frozen and stored in liquid nitrogen in early and later subcultures, such lines can provide a plentiful if not inexhaustible supply of cells. Further studies by Hayflick and other investigators $(2,3)$ have shown that HDC

\footnotetext{
* The research upon which this publication is based was performed pursuant to Contract No. NIH-69-100 with the Division of Biologies Standards of the National Institutes of Health.

${ }^{1}$ Nomenclature for identification of cell lines: DBS, Division of Biologies Standards; F, fetal; Rh, rhesus; C, Cercopithecus; L, lung; K, kidney; $\mathrm{M}$, muscle; S, skin; and $\mathrm{H}$, heart.
}

are karyotypically and morphologically stable during serial culture, are free of detectable viral contaminants, are susceptible to a broad spectrum of viruses, and can be preserved by freezing without loss of properties. One such line (WI-38) is now used as an alternate to primary monkey kidney cells as substrate in the manufacture of live, oral poliovirus vaccine. The numerous advantages of serially cultured cell lines as standardized, pretested cell seed in vaccine production have been reviewed (4).

The experiences with HDC derived from human fetal tissue suggested that similar tissues of other animal species also be explored for their potential usefulness in the development of diploid cell lines. Subhuman primate diploid cell lines offer the advantage of an immense, positive 
clinical experience with viral vaccines produced in primary cell cultures deriving from rhesus (Macaca mulatta) and African green (AG) (Cercopithecus aethiops) monkeys; an additional advantage is the availability of animals for in vivo tumorigenicity testing.

Previous reports on the serial culture of cells from kidney tissues of an AG monkey (5), rhesus monkey fetus (6), and a marmoset monkey (7) suggested the feasibility of establishing diploid cell lines from tissues of subhuman primates.

We have developed 28 cell lines from fetal tissues of rhesus and AG monkeys, and these have been characterized according to the general criteria recommended by the International Cell Committee of the Permanent Section for Microbiological Standardization $(2,3)$. One of these cell lines, DBS-FRhL-2, has been found to have culture characteristics similar to those described for $\mathrm{HDC}$ and to meet the requirements proposed for acceptability as an alternate substrate for virus vaccine production. This cell line is described here. Details of the development and characteristics of the 27 other cell lines are described in an accompanying report (8) for, although rejected as candidates for virus vaccine production, they may be useful in studies requiring standardized cell lines from nonhuman primates. Preliminary results of these studies have been presented $(9,10)$.

\section{Materials and Methods}

Serological tests on monkeys. Pregnant rhesus monkeys were obtained from Primate Imports Corp., Port Washington, Long Island, and from Vita Private, Ltd., Delhi, India. The latter were isolated and held in quarantine for 6 weeks after arrival. AG monkeys were selected from the breeding colony maintained by the Division of Biologies Standards at Bionetics Research Laboratories in Kensington, Maryland.

Monkeys were skin-tested for tuberculosis, examined for malarial and internal parasites, and bled from the femoral artery before removal of the fetus. Sera were tested for antibodies to simian virus $40\left(\mathrm{SV}_{40}\right)$; foamy viruses types I and II; simian cytomegalovirus (CMV); poliovirus types I, II, and III; rubella virus; and measles virus. Antibodies to CMV were determined by the indirect fluorescent-antibody test of Thiel and Smith (11), using human diploid cells, strain Led-130 (12), previously infected with CMV and fixed with methanol. Rubella and measles hemagglutination-inhibiting (HI) antibodies were determined in tests essentially as described by Enders (13), using pigeon erythrocytes for rubella and rhesus or AG monkey erythrocytes for measles virus. Foamy virus and $\mathrm{SV}_{40}$ complement-fixing antibodies were determined by the Micro Laboratory Branch Complement Fixation test (14). Tests for neutralizing antibodies to poliovirus were performed by using the metabolic inhibition test described by Schmidt (15). Tests for viremia were performed by inoculating $0.1 \mathrm{ml}$ of serum into each of three tube cultures of primary AG monkey kidney (AGMK), rabbit kidney (RbK), and Led-130 cells. These cultures were observed microscopically for viral cytopathic effects (CPE) during 14 days incubation at $37^{\circ} \mathrm{C}$.

Fetuses were taken by cesarian section and bled by cardiac puncture; heart, kidneys, lung, skin, and muscle were removed. A portion of each tissue was fixed in formalin for histological examination; remaining tissues were placed in 2-oz jars containing culture medium with antibiotics and delivered to the laboratory where they were prepared for culture the same day. The DBS-FRhL-2 cell line described in this report was derived from lung tissue of a rhesus monkey fetus.

Culture methods. Culture medium used for initiating and propagating the cells was Eagle's minimum essential medium (MEM) containing nonessential amino acids (16), vitamins, and glutamine at twice the usual concentrations and bovine fetal serum at $10 \%$ concentration. Both MEM and bovine fetal serum had been pretested for growth support of human Led-130 cell cultures, and the serum was also tested for bacteria, mycoplasmas, and for bovine viruses. A single lot of MEM, purchased in bulk as powdered medium from Grand Island Biological Co., Grand Island, New York, and two pooled lots of bovine fetal serum from Reheis Chemical Co., Chicago, Illinois, were used throughout these studies. Ponicillin (100 I.U. per ml), streptomycin $(50 \mu \mathrm{g}$ per $\mathrm{ml})$, and neomycin $(20 \mu \mathrm{g}$ per $\mathrm{ml}$ ) were incorporated into the medium only during initial explantation of tissues.

Other media used in comparative studies were CMRL 1969 (17), NCTC 135 (18), RPMI 1640 (19), Eagle's Basal Medium (20), McCoy's 5a 
(21) as modified by Iwakata and Grace (22), 199 (23) and lactalbumin hydrolysate medium (LAPAGT) (12).

Cultures were prepared and maintained in an area isolated from work with infectious agents and other cultured cell lines. Fetal lung tissue was minced and dispersed by three successive treatments with Tris-buffered saline (24) containing $0.25 \%$ trypsin and $0.01 \%$ collagenase. The dissociated cells were passed through a stainless steel sieve, sedimented by contrifugation, and rinsed with Tris-buffered saline. Seven million cells were seeded into each $75 \mathrm{~cm}^{2}$ plastic flask with $25 \mathrm{ml}$ of culture medium, and flasks were incubated at $37^{\circ} \mathrm{C}$ with slightly loose caps in a humidified incubator provided with $5 \% \mathrm{CO}_{2}$ in air. Cultures received a medium change or were subcultured by dispersal of monolayers with $0.01 \%$ crystalline trypsin each 3 to 4 days. Split ratios were $1: 2$ to $1: 4$, depending on population densities; efforts were made to seed subcultures with the minimum numbers of cells required to produce near confluency in 3 to 4 days. Aliquots of cell suspensions were preserved in a $2.0 \%$ solution of citric acid containing crystal violet at $0.1 \%$ concentration for determinations of population densities by cell count. These provided an estimate of population doublings over the 3 - to 4-day growth period as well as total doublings during in vitro life. Culture passages in this report refer to flask passages at split ratios varying from $1: 2$ to $1: 4$; population doublings during the $3-$ to 4 -day growth periods were determined by the formula

[ $\log _{10}$ of (number of cells at $T_{2}$ )]

(number of cells at $T_{0}$ ) $] / \log _{10}$ of 2.0

Population doubling times were determined by the general procedures of Harris (25).

Cells at various passages were suspended in medium containing $7.5 \%$ glycerol or dimethylsulfoxide, sealed into ampoules in $1.0-\mathrm{ml}$ volumes, and stored in liquid nitrogen by methods previously described (12). Cell suspensions were thawed, and viability was determined by direct count of living and dead cells in the presence of $\operatorname{eosin}(12)$.

Tests for adventitious agents, tumorigenicity. The cells were tested at each 10 th passage for the presence of adventitious agents generally as specified by United States Public Health Service regulations for safety testing of biological prod- ucts (26). This included direct tests on the cells for hemadsorbing agents using guinea pig red cells, tests for nuclear inclusions using acridine orange stain, and fluorescent-antibody tests for specific viral antigens of $\mathrm{SV}_{40}, \mathrm{CMV}$, and simian virus $\mathrm{SV}_{5}$. The cells were also tested for positive immunofluorescent reactions to viral antibodies present in maternal serum. Cells and spent media were tested for bacteria, fungi, and mycoplasmas in suitable media and for the presence of viruses by inoculation into cultures of primary AGMK, rhesus monkey kidney (RMK), $\mathrm{RbK}$, and human amnion, as well as cultures of BSC-1 (5) and Led-130 (12). Cell harvests from tests in primary AGMK were subcultured once into other primary AGMK cultures. In vivo tests were also performed by inoculation of cells and spent medium into embryonated hens' eggs, adult mice, suckling mice, and rabbits. Complement fixation and fluorescent-antibody tests for $\mathrm{SV}_{\text {so }}$ tumor " $\mathrm{T}$ " antigen were also performed, using serum from hamsters bearing large, $\mathrm{SV}_{40^{-}}$ induced tumors and methods described by Hucbner et al. (27).

Cells were tested for tumorigenicity in the adult Syrian hamster cheek pouch by the technique of Handler and Foley (28) and in suckling hamsters treated with antithymocyte serum by methods described elsewhere (29). Human epidermoid carcinoma cells, strain $\mathrm{KB}(30)$, were used as a positive control in all tests.

Cytogenetic analysis. Permanent slides of cells in metaphase were prepared at various passages by the air-drying technique (31). Karyotypic constructions were made from photographic enlargements of $4 \times 5$ inch Polaroid negatives. Chromosomes were paired according to the arrangement given for $M$. mulatta and $C$. aethiops by Hsu and Benirschke (32).

Virus susceptibility tests. Viruses used were: the polioviruses type I LSc, type II p712, and type III Leon, Sabin vaccine strains; human adenoviruses type 3 , strain J. F. and type 7 , strain L. L. isolated by Dr. R. J. Huebner, National Institute of Allergy and Infectious Diseases; rhinovirus type 2 HGP, Salisbury strain; rubella, strain M33 HPV-77 obtained from Dr. P. Parkman, Division of Biologics Standards; vaccinia, commercial calf lymph vaccine propagated on chorioallantoic membrane of embryonated hens' eggs; measles, Edmonston strain obtained from Dr. J. Enders, Children's Hospital, 
Boston; human parainfluenza types 2 and 3 obtained from Dr. R. Chanock, National Institute of Allergy and Infectious Diseases; mumps, Angela strain isolated in these laboratories by Dr. C. P. Cerini; Coxsackie $A_{\theta}$ and herpes simplex $\mathrm{HF}$ obtained from the American Type Culture Collection.

Tests were performed on 48 -hr tube cultures. Ten-fold dilutions of each virus were inoculated in 0.1- to $0.2-\mathrm{ml}$ amounts to each of three tubes. Viruses were also titrated simultaneously in control tissue culture systems: the polioviruses, adenoviruses, parainflucnzas, Coxsackie $A_{v}$, and vaccinia in primary cultures of RMK; mumps in primary cultures of AGMK; herpes simplex in cultures of AGMK cell line BSC-1 (5) ; rhinovirus in cultures of Led-130 (12); and rubellia in cultures of AGMK or rabbit kidney, strain $R K_{13}$ (33). Cultures werc incubated 7 to 14 days and read microscopically for viral CPE; TCID ters were calculated by the method of Reed and Muench (34).

\section{RESULTS}

Serological tests on monkeys. Monkeys were screened for viral antibodies with the hope of selecting animals free of latent viral infections which may be present in primate tissues (35), and these results have been reported (10).

Although animals free of overt illness and viremia could be selected, no monkeys were free of antibodies to all viruses tested. The healthy pregnant rhesus monkey used in this study had low levels of serum antibodies to $\mathrm{SV}_{\mathrm{w}}(1: 8)$, foamy virus type I $(1: 32)$, and CMV $(1: 160)$. The fetus removed from this monkey had antibodies to the same viruses at slightly lower levels.

Tests for viremia on maternal and fetal sera were negative, and histological examination of formalin-fixed tissues from the fetus revealed no pathological findings.

Growth characteristics of cultures. The DBSFRhL-2 cell line originated from lung tissue of a 248-g male rhesus monkey fetus.

Cultures of vigorously multiplying fibroblasts were obtained 6 days after seeding with $7.0 \times$ $10^{8}$ dispersed lung cells. Primary cultures contained a few epithelial cell colonies which were lost on subsequent subculture. During the first few subcultivations, flasks were seeded with inocula ranging from $0.5 \times 10^{8}$ to $6.0 \times 10^{8}$ cells to determine the minimum number of cells required to produce near confluent monolayers in 3 to 4 days. Inocula of $1.0 \times 10^{6}$ cells per flask produced subcultures containing approximately $6.0 \times 10^{\prime \prime}$ cells in 3 to 4 days during passages 1 to 8 . In later passages during active growth of the cell line, an inoculum of $1.3 \times 10^{\mathrm{a}}$ cells produced near confluent monolayers of $4 \times 10^{6}$ to $5 \times 10^{4}$ cells in 3 to 4 days. From passage 8 , cultures were regularly subdivided $1: 3$ atach 3 to 4 days during an active growth phise of 44 total culture passages and approximately 67 population doublings. During this time, the population doubling time of the cells averaged $33 \mathrm{hr}$.

Cultures in active growth were composed of oval to spindle-shaped fibroblasts, loosely connected by cytoplasmic processes (sce Fig. 1). In densely populated areas, the cells appeared to grow in an orderly orientation suggesting some inhibition of movement upon contact with other cells.

After 44 passages and 6 months in culture, the growth rate of the cells slowed noticeably, and the cultures were subdivided $1: 2$ each 4 to 10 days during the next 3 months. The cells ceased to multiply beyond passage 51, after approximately 74 total population doublings. Cultures from passilges 48 to 51 were composed of some multinucleate and many enlarged and/or vacuolated cells which subsequently ceased to proliferate and degenerated or became detached from the flaski. Senescent cultures in passages 50 and 51 received medium changes once or twice each week during a 3 -month period in which they were observed for eell morphological changes or resumption of cell division. The cultures were discarded when all cells had degenerated or become detached from the flasks.

Colls frozen at various passages have been recovered from storage in liquid nitrogen with cell viability ranging from 60 to $85 \%$ and returned to culture without apparent change in growth characteristics. In experiments on freeze survival, highest viability was obtained when no more than $4 \times 10^{6}$ cells per ampule were frozen, when dimethylsulfoxide was the cryoprotective agent, and when a controlled freezing rate of about $1^{\circ} \mathrm{C}$ per min was maintained during the critical phase from $0^{\circ} \mathrm{C}$ to $-25^{\circ} \mathrm{C}$.

DBS-FRhL-2 cultures have been recovered from frozen storage in passages $15,25,40$, and 43 and propagated through their remaining 


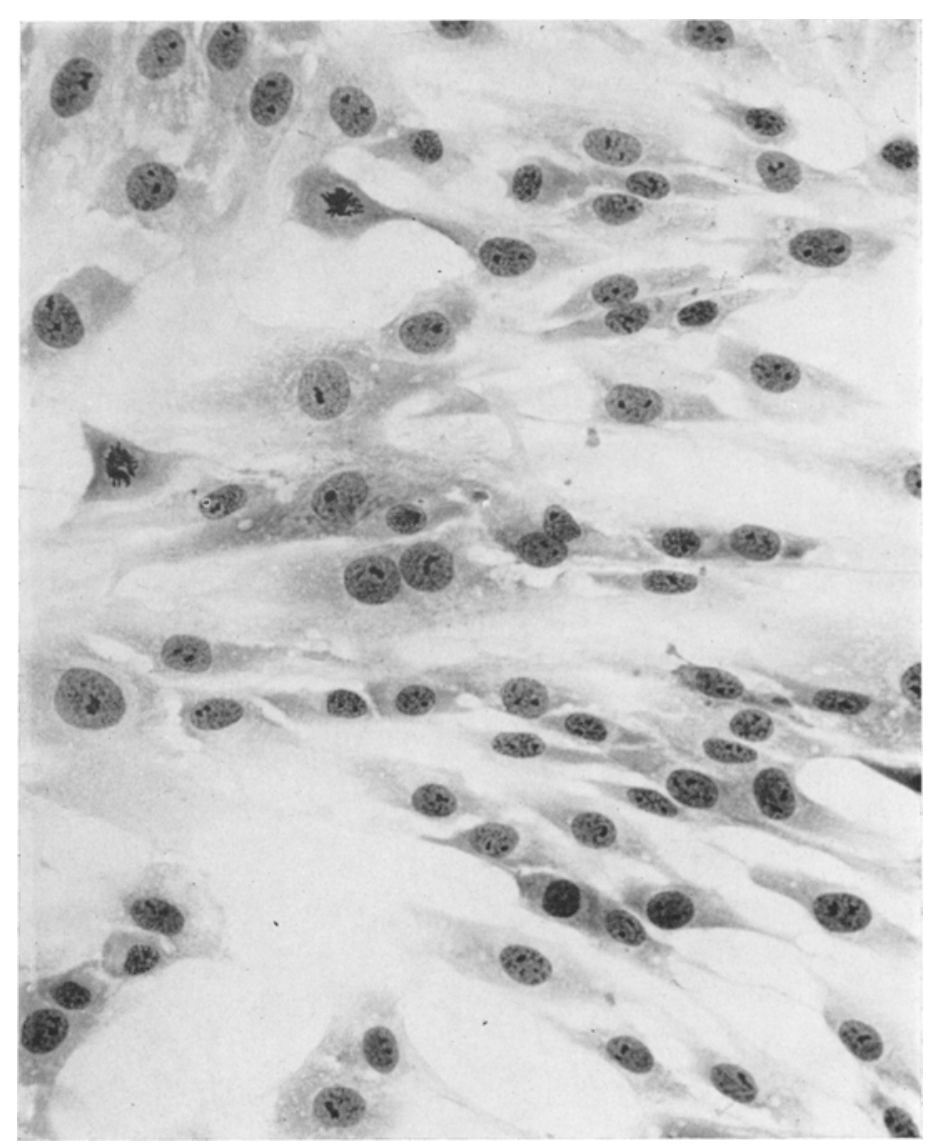

FIG. 1. Fetal rhesus monkey diploid cells DBS-FRhL-2, passage 26. Giemsa stain. $\times 220$.

finite life. Fifteen to 20 cultures of each series were maintained through growth decline and senescence and observed for changes in cell morphology or growth properties. Each series entered growth decline after 35 to 44 total passages and ceased cell multiplication after 60 to 73 population doublings.

Tests for tumorigenicity, using $2.5 \times 10^{5}$ to $10^{n}$ cells per site of inoculum in both adult and suckling hamsters, were performed at passages $20,24,29,31,40$, and 47 . All tests were negative. Human epidermoid carcinoma (KB) cells, which were included as controls in each test and inoculated at $2.5 \times 10^{5}$ cells per site, produced progressively growing tumors in both adult and suckling hamsters.

Cytogenetic analysis. DBS-FRhL-2 cells were found to be predominantly diploid with polyploid levels below $2.0 \%$ at all passages examined during their active growth phase (see Table 1).
As shown, over-all hypodiploidy and hyperdiploidy were 6.3 and $1.3 \%$, respectively, during passages 22 through 40 . An increase in polyploidy to $11.2 \%$ and chromosome structural abnormalities to $2.8 \%$ was observed only in aging cultures at passages 45 to 46 . The structural abnormalities observed were unstable dicentric forms. A photograph and karyotype of a DBSFRhL-2 cells in passage 27 is shown in Fig. 2.

Growth of diploid cells in various culture media. To determine whether a monkey diploid cell line established in MEM could be propagated satisfactorily in tissue culture media of different formulation, comparative studies were made using some of the conventional culture media: CMRL 1969, NCTC 135, RPMI 1640, Eagle's BME, McCoy's 5a, 199, and lactalbumin hydrolysate-LAPAGT medium. AII media were supplemented with bovine fetal serum at $10 \%$ concentration. 
TABI.E 1

Karyological Data on Rhesus Monkey Diploid Cells, DBS-Fihhi-2 (2N = 42)

\begin{tabular}{|c|c|c|c|c|c|}
\hline $\begin{array}{l}\text { Culture } \\
\text { Passage }\end{array}$ & $\begin{array}{c}\text { Hypodiploidy } \\
(\%)\end{array}$ & $\underset{(\%)}{\text { Hyperdiploidy }}$ & $\begin{array}{c}\text { Polyploidy } \\
(\%)\end{array}$ & $\begin{array}{c}\text { Breaks and Gaps } \\
(\%)\end{array}$ & $\begin{array}{c}\text { Structural } \\
\text { Abnormalities }(\%)\end{array}$ \\
\hline $22-25$ & $48 / 1000(4.8)$ & $13 / 1000(1.3)$ & $53 / 3300(1.6)$ & $50 / 1100(4.5)$ & $7 / 1100(0.6)$ \\
\hline $26-31$ & $56 / 700(8.0)$ & $10 / 700(1.4)$ & $50 / 3300(1.5)$ & $37 / 1100(3.4)$ & $21 / 1100(1.9)$ \\
\hline $32-40$ & $35 / 500(7.0)$ & $6 / 500(1.2)$ & $64 / 2700(2.4)$ & $20 / 900(2.2)$ & $17 / 900(1.5)$ \\
\hline $45-46$ & $45 / 106(42.0)$ & $3 / 106(2.8)$ & $69 / 611(11.2)$ & $6 / 106 \quad(5.6)$ & $3 / 106(2.8)^{*}$ \\
\hline $\begin{array}{r}\text { Over-all } \\
22-40\end{array}$ & $139 / 2200(6.3)$ & $29 / 2200(1.3)$ & $167 / 9300(1.8)$ & $107 / 3100(3.4)$ & $45 / 3100(1.4)$ \\
\hline
\end{tabular}

* Three dicentrics.

DBS-FRhL-2 cells were harvested by trypsin dispersal from cultures which had been propagated through 9 to 12 passages in MEM. Culture flasks were inoculated each with $1.3 \times 10^{\circ}$ cells and grouped, three flasks per group, to receive the test media. Cultures were incubated and observed during 39 days; they received a medium renewal each 3 to 4 days and were subdivided when confluent at split ratios of $1: 2$ or $1: 3$ depending on the population density.
Cultures in each group were prepared for cytogenetic analysis at the end of the observation period. Results are summarized in Table 2.

Cells in MEM, CMRL 1969, NCTC 135, and RPMI 1640 multiplied actively through 10 passages (13 to 15.8 population doublings) and required subculture at split ratios of $1: 3$ each 3 to 4 days. Cells in BME also multiplied satisfactorily through nine passages (10.2 population doublings). Cultures were composed of healthy, ac-

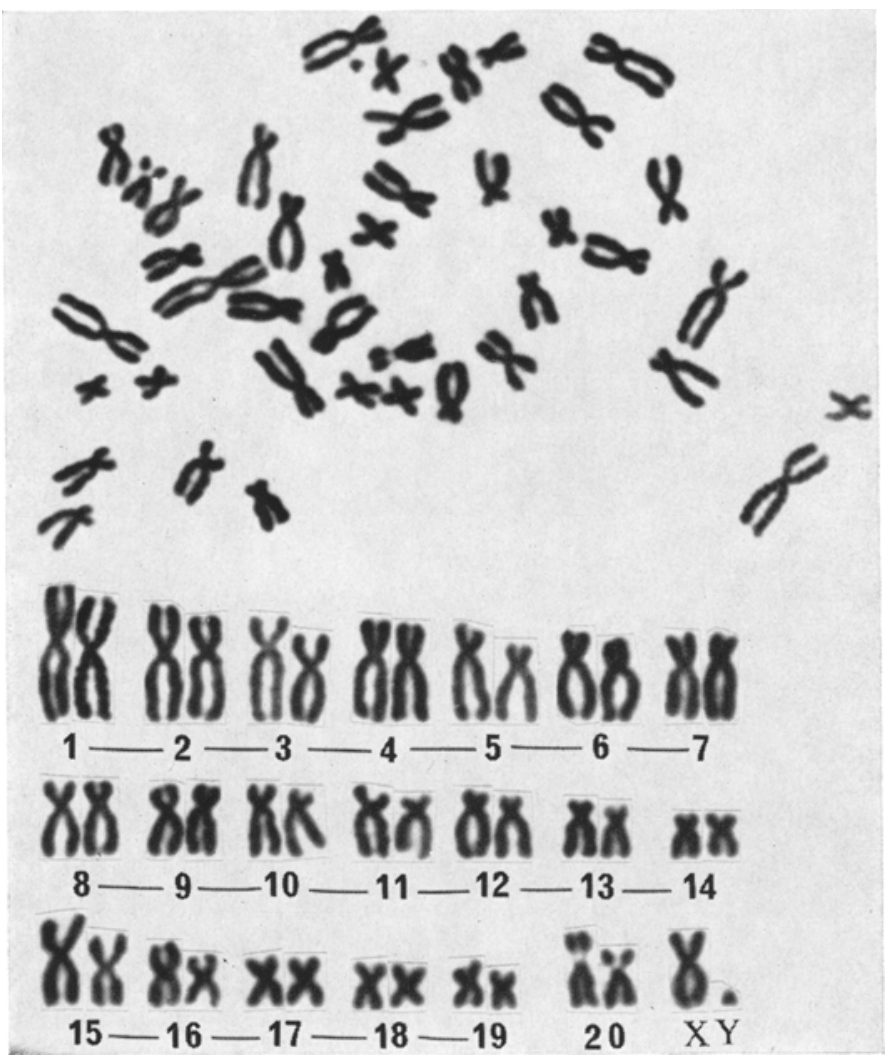

Fic. 2. Male rhesus monkey diploid cell and its karyotype. Rhesus monkey lung line DBS-FRhL-2, passage 27. 
TABLI: 2

Effect of Culture Midium on Growth and Polyploidy of Rhesus Monkey Diploid CELLS, DBS-FPhL-2

\begin{tabular}{|c|c|c|c|c|}
\hline \multirow{2}{*}{ Medium* } & \multicolumn{2}{|c|}{$\begin{array}{l}\text { Growth during } \\
39 \text { Days }\end{array}$} & \multirow{2}{*}{$\begin{array}{l}\text { Condition } \\
\text { of Cells in } \\
\text { Final Passage }\end{array}$} & \multirow{2}{*}{$\begin{array}{l}\text { Per } \\
\text { cent } \\
\text { Poly- } \\
\text { ploids }\end{array}$} \\
\hline & $\begin{array}{l}\text { Cul- } \\
\text { ture } \\
\text { pas- } \\
\text { sages }\end{array}$ & $\begin{array}{l}\text { Popu- } \\
\text { lation } \\
\text { dou- } \\
\text { blings }\end{array}$ & & \\
\hline MEM & 10 & 15.8 & Good & 0.6 \\
\hline CMRL 1969 & 10 & 15.7 & Good & 1.9 \\
\hline NCTC 135 & 10 & 13.4 & Good & 0.6 \\
\hline RPMI 1640 & 10 & 13.0 & Good & 2.2 \\
\hline BME & 9 & 10.2 & Good & 1.9 \\
\hline MeCoy's 5a & 9 & 9.6 & $\begin{array}{l}\text { Poor, granu- } \\
\text { lar }\end{array}$ & 0.3 \\
\hline 199 & 7 & 7.6 & Poor, aged & 0.6 \\
\hline LAPAGT & 5 & 5.0 & Poor, aged & 10.9 \\
\hline
\end{tabular}

* All media 'were supplemented with bovine fetal serum at $10 \%$ concentration.

$\dagger$ Observations were based on at least 300 cells per sample.

tively proliferating cells after 39 days of continued growth in BME, MEM, CMRL 1969, NCTC 135, and RPMI 1640. Cell multiplication slowed after 9 passages in McCoy's 5a and ceased after five to seven passages in LAPAGT and 199 media; cells propagated in LAPAGT and 199 media also developed cellular changes associated with senescence.

Cytogenetic examination of these cultures revealed no significant chromosome changes in cells propagated in MEM, CMRL 1969, NCTC 135, BME, or RPMI 1640 medium. Polyploidy ranged from 0.3 to $2.2 \%$ of 300 cells observed in each of the above media, whereas cells propa- gated in LAPAGT medium developed a polyploid level of $10.9 \%$. The frequency of chromatid and chromosome breaks in LAPAGT and 199 media was two to three times that observed in the other test media.

Viral susceptibility, tests for adventitious agents. The DBS-FRhL-2 line was found susceptible to a number of human viruses. Results of representative tests are shown in Table 3 . The cells were comparable to control culture systems in sensitivity to the polioviruses, parainfluenza type 3, rhinovirus HGP, rubella, Coxsackie $A 9$, and vaccinia and were insensitive to the other viruses tested (human adenovirus types 3 and 7 , parainfluenza virus type 2 , mumps and measles). No change in viral sensitivity was noted with continued culture passage.

To investigate rubella and poliovirus production in this diploid cell line, $75 \mathrm{~cm}^{2}$ flask cultures of DBS-FRhL-2 cells in passage 38 were infected with $10^{5.0} \mathrm{TCID}_{50}$ of poliovirus type I or $10^{4.0} \mathrm{TCID}_{\tilde{x} 0}$ of rubella virus. Cultures infected with poliovirus were placed at $34^{\circ} \mathrm{C}$, and $1-\mathrm{ml}$ samples were removed for viral assay at intervals during $72 \mathrm{hr}$ of incubation. Rubella virusinfected cultures were incubated at 32 or $36^{\circ} \mathrm{C}$ and received a medium change each 2 to 4 days.

Cultures produced peak titers of $10^{7.7}$ to $10^{8.2}$ TCID $_{50}$ per $\mathrm{ml}$ of poliovirus after $48 \mathrm{hr}$ when about $75 \%$ of the cells were destroyed by virus. These titers were sustained through the remaining period of incubation. Rubella virus titers of culture fluids removed at 2- to 4-day intervals ranged from 3.6 to $6.0 \mathrm{TCID}_{\mathrm{so}}$ per ml during 35 to 39 days at $36^{\circ} \mathrm{C}$ and 71 to 76 days at $32^{\circ} \mathrm{C}$. No significant difference in titers was

TABLE 3

Virus Susceptibility of Rhesus Monkey Diploid Cells, DBS-FRhL-2

\begin{tabular}{|c|c|c|c|c|c|c|c|c|c|c|c|c|c|c|}
\hline \multirow{2}{*}{$\begin{array}{l}\text { Cul- } \\
\text { ture } \\
\text { Pas- } \\
\text { sag }\end{array}$} & \multicolumn{3}{|c|}{ Poliovirus } & \multicolumn{2}{|c|}{ Adenovirus } & \multicolumn{2}{|c|}{ Parainfluenza } & \multirow{2}{*}{$\begin{array}{c}\text { Herpes } \\
\text { Sim- } \\
\text { plex }\end{array}$} & \multirow{2}{*}{ Mumps } & \multirow{2}{*}{$\begin{array}{l}\text { Rhino- } \\
\text { virus } \\
\text { HGP }\end{array}$} & \multirow{2}{*}{$\begin{array}{c}\text { Ru- } \\
\text { bella }\end{array}$} & \multirow{2}{*}{$\begin{array}{c}\text { Cox- } \\
\text { sackie } \\
\text { A9 }\end{array}$} & \multirow{2}{*}{$\begin{array}{l}\text { Vac- } \\
\text { cinia }\end{array}$} & \multirow{2}{*}{$\begin{array}{l}\text { Mea- } \\
\text { sles }\end{array}$} \\
\hline & $\mathbf{I}$ & II & III & 3 & 7 & 2 & 3 & & & & & & & \\
\hline 14 & $\begin{array}{c}4.4^{*} \\
(5.7) \dagger\end{array}$ & $\begin{array}{c}5.2 \\
(6.2)\end{array}$ & $\begin{array}{c}6.9 \\
(6.4)\end{array}$ & $\begin{array}{c}2.9 \\
(4.2)\end{array}$ & $\begin{array}{c}1.7 \\
(2.4)\end{array}$ & $\begin{array}{c}4.4 \\
(4.4)\end{array}$ & $\begin{array}{c}3.2 \\
(4.2)\end{array}$ & $\begin{array}{c}3.2 \\
(4.2)\end{array}$ & $\begin{array}{c}3.2 \\
(4.2)\end{array}$ & $\begin{array}{c}5.9 \\
(6.2)\end{array}$ & $\begin{array}{c}4.2 \\
(3.5)\end{array}$ & $\begin{array}{c}7.2 \\
(7.4)\end{array}$ & $\begin{array}{c}8.4 \\
(8.0)\end{array}$ & $\begin{array}{c}2.2 \\
(5.2)\end{array}$ \\
\hline 20 & $\begin{array}{c}6.2 \\
(5.7)\end{array}$ & $\begin{array}{c}6.4 \\
(6.7)\end{array}$ & $\begin{array}{c}7.4 \\
(7.7)\end{array}$ & $\begin{array}{c}1.2 \\
(4.4)\end{array}$ & $\begin{array}{c}1.2 \\
(2.2)\end{array}$ & $\begin{array}{c}2.2 \\
(4.1)\end{array}$ & $\begin{array}{c}6.9 \\
(5.9)\end{array}$ & $\begin{array}{c}1.2 \\
(5.2)\end{array}$ & $\begin{array}{c}3.9 \\
(5.2)\end{array}$ & $\begin{array}{c}4.2 \\
(5.2)\end{array}$ & 3.2 & $\begin{array}{c}7.2 \\
(8.2)\end{array}$ & $\begin{array}{c}8.9 \\
(8.4)\end{array}$ & $\begin{array}{c}2.9 \\
(5.2)\end{array}$ \\
\hline 30 & $\begin{array}{c}6.0 \\
(5.7)\end{array}$ & $\begin{array}{c}6.9 \\
(6.7)\end{array}$ & $\begin{array}{c}6.9 \\
(7.7)\end{array}$ & $\begin{array}{c}2.4 \\
(4.4)\end{array}$ & $\begin{array}{c}1.2 \\
(2.2)\end{array}$ & $\begin{array}{c}2.2 \\
(4.1)\end{array}$ & $\begin{array}{c}6.9 \\
(5.9)\end{array}$ & $\begin{array}{c}1.2 \\
(5.2)\end{array}$ & $\begin{array}{c}2.2 \\
(5.2)\end{array}$ & $\begin{array}{c}5.2 \\
(5.2)\end{array}$ & 4.2 & $\begin{array}{c}6.9 \\
(8.2)\end{array}$ & $\begin{array}{c}8.9 \\
(8.4)\end{array}$ & $\begin{array}{c}4.2 \\
(5.2)\end{array}$ \\
\hline
\end{tabular}

* Reciprocal $\log _{10}$ of the TCII 50 per ml.

$\dagger$ Figures in parentheses are titers obtained in control culture systems. 
noted in cultures maintained at 32 or $36^{\circ} \mathrm{C}$. Cellular degeneration, noted after 35 days in rubella-infected cultures held at $36^{\circ} \mathrm{C}$, became more extensive resulting in death of the cultures after 50 days at $36^{\circ} \mathrm{C}$ and after 76 days at $32^{\circ} \mathrm{C}$.

Pilot lots of poliovirus and rubella virus vaccines have been produced in cultures of DBSFRhL-2 propagated and maintained under conditions currently used in the manufacture of poliovirus vaccine. Viral titers of polio and rubella virus vaccines produced under these conditions compared favorably with titers of these vaccines produced in primary cultures of AGMK. Detailed results of these experiments will be reported elsewhere.

All tests for mycoplasmas, bacteria, and fungi and all in vitro and in vivo tests on these cells for viral agents or their antigens have been negative.

\section{Discussion}

On the recommendations of the 1967 Cell Culture Conference (4), studies were undertaken to develop nonhuman diploid cell lines which could be used in the manufacture of virus vaccines. Twenty-eight cell lines were developed from fetal tissues of rhesus and AC monkeys, and our studies show that one of these, DBS-FRhL-2, deriving from lung tissue of a rhesus monkey fetus, has characteristics which meet the requirements of populations proposed as substrates for virus vaccines $(2,3)$. The other lines which were rejected as candidates for virus vaccine production are described in the accompanying report (8).

A critical evaluation of the cytogenetic characteristics of cell lines derived from rhesus or AG monkeys requires karyological data on primary cultures from both species. Although the diploid number and karyotype of both species have been established, no information on the types and frequency of chromosome aberrations or polyploidy could be found in the literature. A separate study to establish the cytogenetic characteristics of normal rhesus and $\mathrm{AG}$ monkey cells was begun and will be reported clsewhere (36) .

The DBS-FRhL-2 coll line deseribed in this report maintains a stable cell morphology and a diploid karyotype during an active growth phase of approximately 67 population doublings. At the end of this time, the cells enter a declining growth period followed by senescent changes which end in cell death.

These cells were nontumorigenic when tested at various culture passages by inoculation intradermally into the cheek pouch of cortisonetreated weanling hamsters and subcutaneously in suckling hamsters treated with antithymocyte serum. More recent tests have been performed in rhesus monkeys treated with antithymocyte serum globulin with negative results (37).

Viral susceptibility studies indicate that DBS-FRhL-2 cells maintain the sensitivity of primary cell cultures of rhesus monkey kidney to a number of human viruses, and results of tests on poliovirus and rubella virus production show DBS-FRhL-2 cells capable of producing these viruses in titers comparable to that usually obtained in primary cell cultures of AGMK.

DBS-FRhL-2 cells which have been frozen in medium containing glycerol or dimethylsulfoxide and stored in liquid nitrogen for periods up to 3 years have been recovered with 60 to $85 \%$ viability. Cells recovered from the frozen state have shown no changes in virus susceptibility or in cytogenetic or growth characteristics.

Repeated tests on this cell line for viral and other adventitious agents have been negative.

Rhesus monkey diploid cell line DBS-FRhL-2 has cytogenetic, growth, and virus susceptibility characteristies which suggest additional studies to evaluate further its acceptability as a substrite in the manufacture of human virus vaccincs. Preliminary work in a number of other laboratories on DBS-FRhL-2 cells has been consistent with the results reported here.

\section{REFERENCES}

1. Hayflick, I.., and P. S. Moorhead. 1961. The serial cultivation of human diploid cell strains. Exp. Cell Res. 25 : 585-621.

2. Procecdings Symposium. 1963. Characterization and uses of human diploid cell strains. Permanent Section for Microbiological Standardization, Opatija, Yugoslavia.

3. Proceedings Symposium. 1968. Oncogenicity of virus vaccines. Yugoslav Academy of Sciences and Arts, Zagreb, Yugoslavia.

4. Conference on eell altures for virus vaceine production. 1968. Nat. Cancer Inst. Monogr. 29.

5. Hopls H. E., I3. C. Bernheim, A. Nisalak, J. H. Tjio, and J. E. Smadel. 1963. Biologic characteristics of a continuous kidney rell line derived from tle African green monkey. J. Immunol. $91: 416-424$. 
6. Forman, M. L., S. Inhorn, E. Sheaff, and J. Cherry. 1969. Biological characteristics and viral spectrum of serially cultivated fetal rhesus monkey kidney cells. Proc. Soc. Exp. Biol. Med. 131 : 1060-1067.

7. Marczynska, B., G. Treu-Sarnat, and F. Deinhardt. 1970. Characteristics of long-term marmoset cell cultures spontaneously altered or transformed by Rous sarcoma virus. J. Nat. Cancer Inst. 44: 545-572.

8. Wallace, R. E., P. J. Vasington, J. C. Petricciani, H. E. Hopps, D. E. Lorenz, and Z. Kadanka. 1972. Development and characterization of cell lines from subhuman primates. In Vitro 8: 333-341.

9. Wallace, R. E., P. J. Vasington, J. C. Petricciani, H. E. Hopps, and D. E. Lorenz. 1971. Diploid cell lines from subhuman primates as substrates for virus vaccine production. Presented at the 12th International Congress for Microbiological Standardization. Annecy, France, September 20-24, 1971 .

10. Petricciani, J. C., H. E. Hopps, and D. E. Lorenz. 1971. Subhuman primate diploid cells: possible substrates in vaccine production. Science 174: 1025-1027.

11. Thiel, J. F., and K. O. Smith. 1967. Fluorescent focus assay of viruses on cell monolayers in pastic petri dishes. Proc. Soc. Exp. Biol. Med. 125: 892-895.

12. Wallace, R. E. 1964. Studies on preservation by freezing of human diploid cell strains. Proc. Soc. Exp. Biol. Med. 116: 990-998.

13. Enders, J. F. 1964. Measles virus (rubeola). In: E. Lennette and N. Schmidt (Eds.), Diagnostic Procedures for Viral and Ricketlsial Diseases, 3rd ed. American Public Health Association, Inc.

14. Standardized Diagnostic Complement Fixation Method and Adaptation to Micro Test. 1965. Monogr. No. 74. U. S. Public Health Service Publication No. 1228.

15. Schmidt, N. J. 1964. Tissue culture methods and procedures for diagnostic virology. In : E. Lennette and N. Schmidt (Eds.), Dirgnostic Procedures for Viral and Rickettsial Diserses. 3rd ed. American Public Health Association, Inc.

16. Eagle, H. 1959. Amino acid metabolism in mammalian cell cultures. Science 130: 432437.

17. Healy, G. M.. S. Teleki, A. U. Seefried, M. J. Walton, and H. G. Macmorine. 1971. Improved chemically defined basal medium (CMRL 1969) for primary monkey kidney and human diploid cells. Appl. Microbiol. 21: 1-5.

18. Evans, V. J., J. C. Bryant, H. A. Kerr, and F. L. Schilling. 1964. Chemically defined media for cultivation of long-term cell strains from four mammalian species. Exp. Cell. Res. 36: $\mathbf{4 3 9 - 4 7 4 . ~}$
19. Moore, G. E., R. E. Gerner, and H. Franklin. 1967. Culture of normal human leukocytes. J.A.M.A. 199: 519-524.

20. Eagle, H. 1956. The growth rosponse of mammalian cells in tissue culture to L-glutamino and I-glutamic acid. J. Biol. Chem. 218: 607616.

21. McCoy, T. A., M. Maxwell, and P. F. Kruse. 1959. Amino acid requirements of the Novikoff hepatoma in vitro. Proc. Soc. Exp. Biol. Med. 100: 115-118.

22. Iwakata, S., and J. T. Grace, Jr. 1964. Cultivation in vitro of myeloblasts from human leukemia. N.Y. J. Med. 64: 2279-2282.

23. Morgan, J. F., H. J. Morton, and R. C. Parker. 1950. Nutrition of animal cells in tissue culture. I. Initial studies on a synthetic medium. Proc. Soc. Exp. Biol. Med. 73: 1-8.

24. Temin, H. 1963. Further evidence for a converted, non-virus-producing state of Rous sarcoma virus-infected cells. Virology 20: 235-245.

25. Harris, M. 1957. Qualitative growth studies with chick myoblasts in glass substrate cultures. Growth 21 : 149-166.

26. United States Public Health Service Requirements. Biological Products. 1970. Title 42, part 73.

27. Huebner, H. J., W. R. Rowe, H. C. Turner, and W. T. Lane. 1963. Specific adenovirus complement-fixing antigens in virus-free hamster and rat tumors. Proc. Nat. Acad. Sci. U. S. A. 50: $379-389$.

28. Handler, A. H., and G. E. Foley. 1956. Growth of human epidermoid carcinomas (strains $\mathrm{KB}$ and $\mathrm{HeL} \mathrm{a}$ ) in hamsters from tissue culture inocula. Proc. Soc. Exp. Biol. Med. 91 : $237-240$.

29. Wallace, R. E., P. J. Vasington, and J. C. Petriceiani. 1971. Heterotransplantation of cultured cell lines in newborn hamsters treated with antilymphocytic serum. Nature (Jondon) 230: 454-455.

30. Eagle, H. 1955. Propagation in a fluid medium of a human epidermoid carcinoma, strain KB. Proc. Soc. Exp. Biol. Med. 89 : 362-364.

31. Moorhead, P. S., and P. C. Nowell. 1964. Chromosome Cytology. In: H. N. Eisen (Ed.), Methods in Medical Research, 10. Yearbook Medical Publishers, Chicago, pp. 310-322.

32. Hsu, T. C., and K. Benirschke. 1967 and 1969. In: An Atlas of Mammalian Chromosomes, Vols. 1 and 3. Springer-Verlag, New York, Inc.

33. Beale, A. J., G. Christofinis, and I. G. Furminger. 1963. Rabbit cells susceptible to rubella virus. Lancet $2: 640-641$.

34. Reed, Is. J., and H. Muench. 1938. A simple method of estimating fifty percent endpoints. Am. J. Hyg. 27 : 493-497.

35. Hsuing, G. D. 1968. Latent virus infections in 
primate tissues with special references to simian viruses. Bacteriol. Rev. 32 : 185-205.

36. Hsu, T. C., Principal investigator; J. E. K. Cooper, Project investigator. Research Contract NIH-70-2247 with University of Texas.
37. Petricciani, J. C., R. L. Kirschstein, R. E. Wallace, and D. P. Martin. 1972. Tumorigenicity of cell lines in subhuman primates treated with antilymphocyte globulin (abstr.) In Vitro 7 : 243.

The skilled technical assistance of Mrs. Edna Schuler, Miss Mary Fox, Mrs. Lois Larroy, and Mr. W. J. Boss is gratefully acknowledged. We are also indebted to Dr. George R. Sharpless and his group in Quality Control for tests of tumorigenicity, viral sensitivity, and tests for adventitious agents, and to Dr. R. J. Vallancourt for performing the caesarian sections. We also thank Dr. T. C. Hsu and Dr. J. E. K. Cooper at the University of Texas for their help in the cytogenetic analyses. 